\title{
COMMUNICATIONS
}

\section{SENILE CHANGES IN THE GANGLION CELLS OF THE HUMAN RETINA*}

\author{
BY \\ F. VRABEC $\dagger$ \\ Institute of Ophthalmology, University of London
}

IN a previous paper (Vrabec, 1965) changes in the axons of the retinal ganglion cell in aged people were described. Similar spherical swellings of axons have also been found in voluntary muscles by Coërs and Woolf (1959) and in the human optic nerve, retina, and ciliary body by Wolter $(1957,1963)$.

This paper deals with other changes in the retinal ganglion cell bodies, axons, and dendrites.

\section{Material and Methods}

Whole mounts of sixteen human adult retinae were studied. Retinal mounts were impregnated by the method of Gros-Schultze, which was slightly modified by shortening the time of impregnation in the 20 per cent. silver nitrate bath to 10 to 15 minutes instead of 1 to 2 hours. Human retinae from the fourth to the ninth decade were studied, ten being between 70 and 85 years. After impregnation, the whole retinae (with cross incisions in the four oblique meridians at the periphery to facilitate flattening) were mounted in Canada balsam, with the inner surface uppermost. Several retinae of other vertebrates were studied for comparison. As the retinae were mounted whole, the danger of artefacts due to breakage was avoided. It was possible, by focusing the microscope upon a particular lamina of the inner plexiform layer, to study the dendrites of large, diffuse ganglion cells spreading horizontally over wide areas, but vertically orientated dendrites could be followed only with some difficulty. High-power dry lenses with longer working distance were most useful for this work. A light compression of the mount, using a small weight during the setting of the resin, permitted the study of fine details of axons and dendrites.

Anterior segments of the same eyes were cut in thick sections $(60$ to $100 \mu)$ on the freezing microtome and impregnated by the original Gros-Schultze method.

\section{Findings}

In aged retinae severe degeneration of the whole cell body occasionally occurs. Such cells are full of detritus and their dendrites are packed with argyrophilic granules (Figs 1 and 2).

The other changes which are described below are, however, much more usual.

* Received for publication December 7, 1964.

$\dagger$ Research Fellow of the Institute of Ophthalmology. 


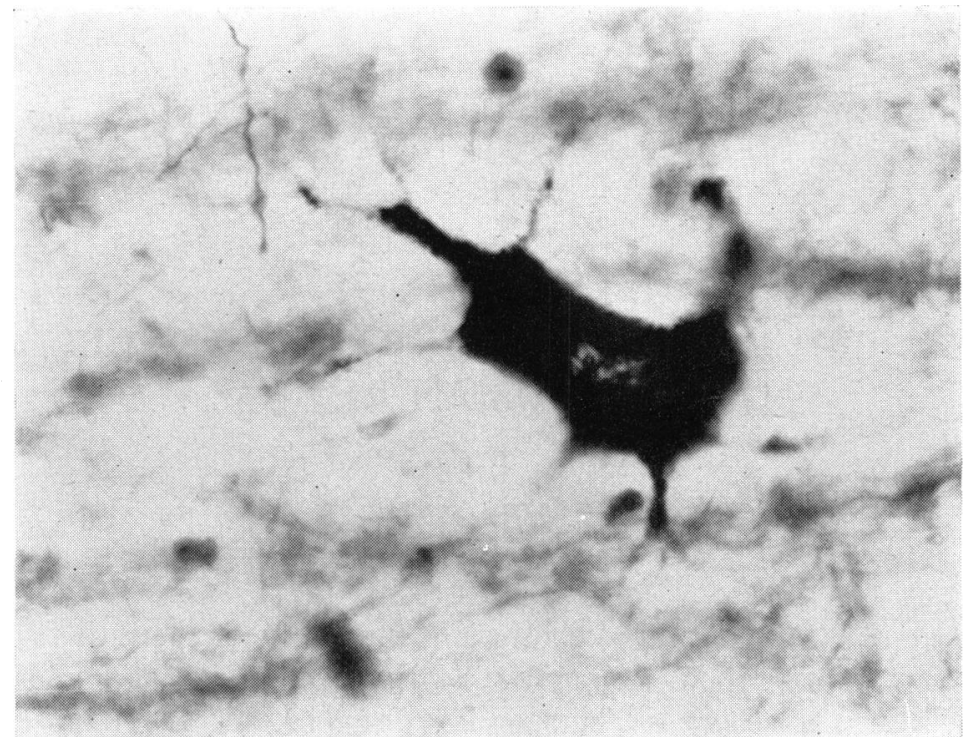

FIG. 1.-Retinal ganglion cell (aged 85 years). The cell body, with the exception of the remnant of the nucleus, is contracted and full of argyrophilic matter. The dendrites are contracted and except for some sparse granules only faintly impregnated. $\times 380$

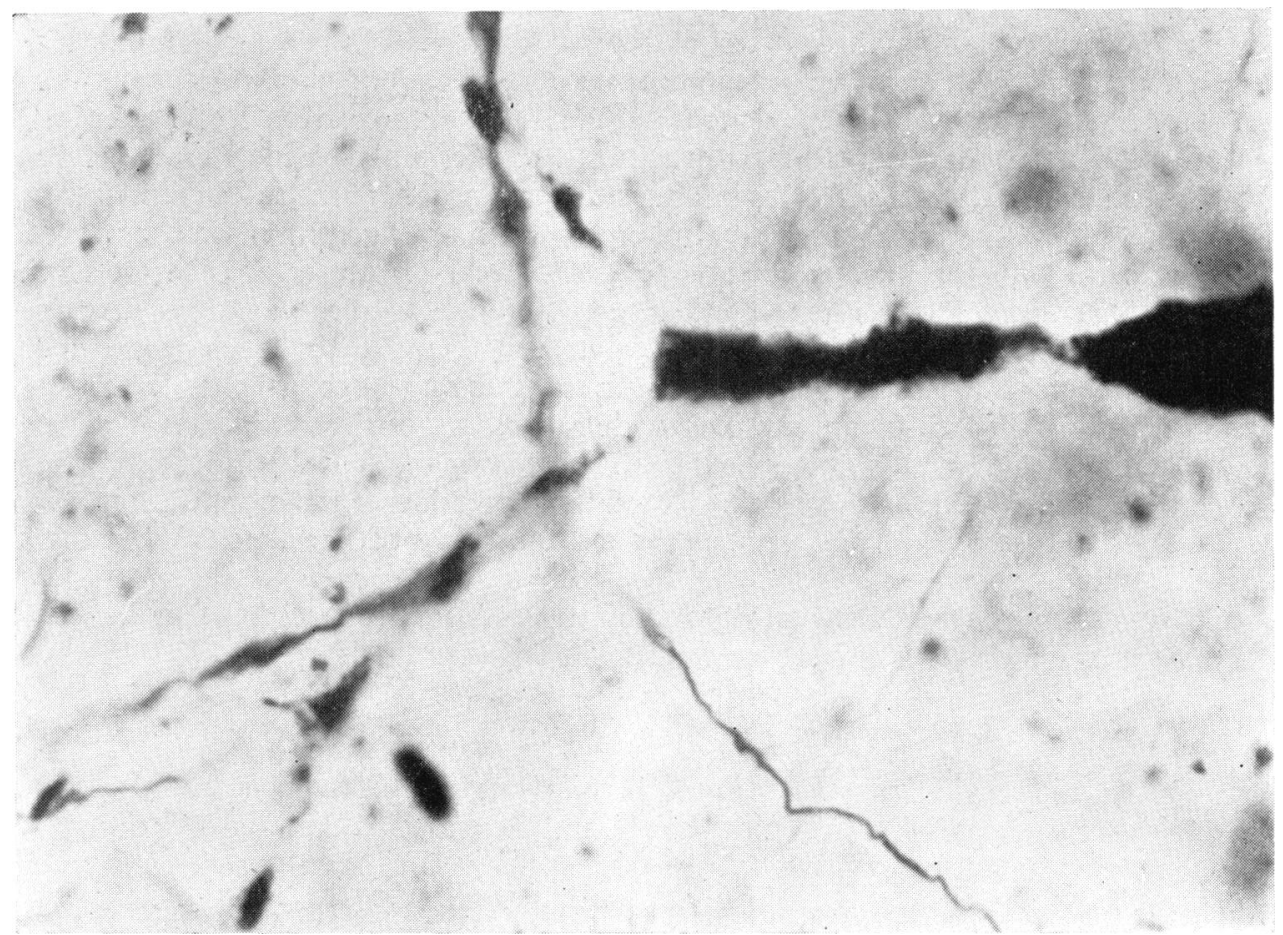

Fig. 2.-Portion of another similarly changed cell in the same retina, showing part of a dendrite containing argyrophilic granules. $\times 800$ 
Dendrites.- Normal dendrites of the retinal ganglion cells appear in the whole mount as long, smooth, branching, protoplasmic processes. They can be followed through wide areas and run almost straight to very fine endings. The thinning of branches to the end is slow and regular, only their divisions being sometimes webbed over by short, triangular membranes (Fig. 3).

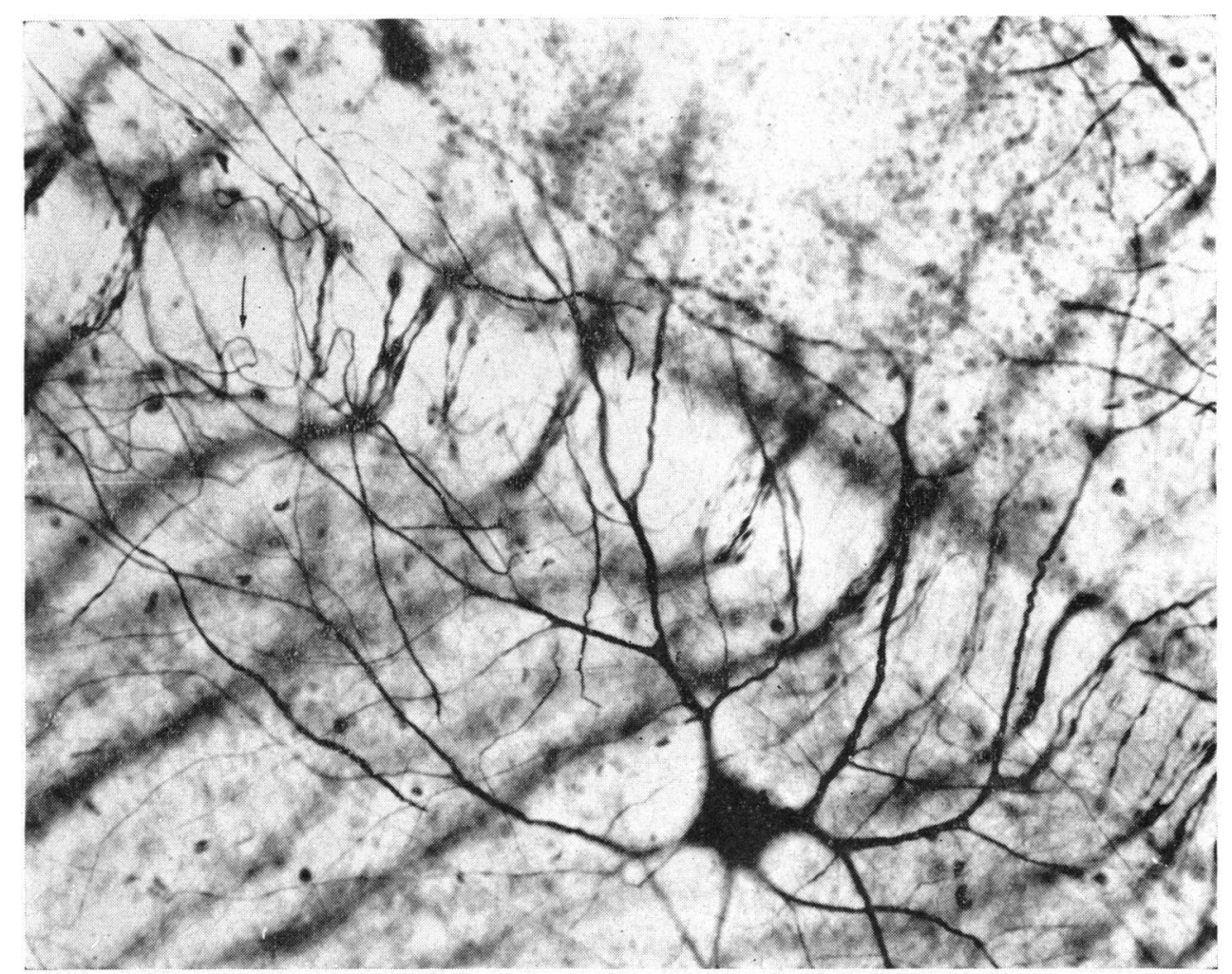

Fig. 3.-Retinal ganglion cell of the ox. Most dendrites are normal, one or two are sinuous (arrow). None is swollen. $\times 160$

At the first indication of senile change, one or more of the dendrites of one cell was seen to follow a tortuous course similar to that of new sprouting nerve fibres in aged corneae (Vrabec, 1955a). This change was most frequent in dendrites meeting some obstacle such as a retinal artery in their normal path (Fig. 3). The remaining dendrites of the same cell were apparently normal.

Another early change was the gross enlargement of an isolated dendrite which was often surprisingly elongated and very intensely impregnated (Fig. 4), showing many fusiform or spherical enlargements.

Fine, regular, smooth fibres were often found sprouting from such enlargements at the periphery (Figs 5 and 6). In other cases, most of the dendrites of a ganglion cell changed at the same time and ended in simple retraction balls or in fusiform growth cones (Fig. 7). Cells were sometimes found with numerous dendrites ending in both balls and cones (Fig. 8). 


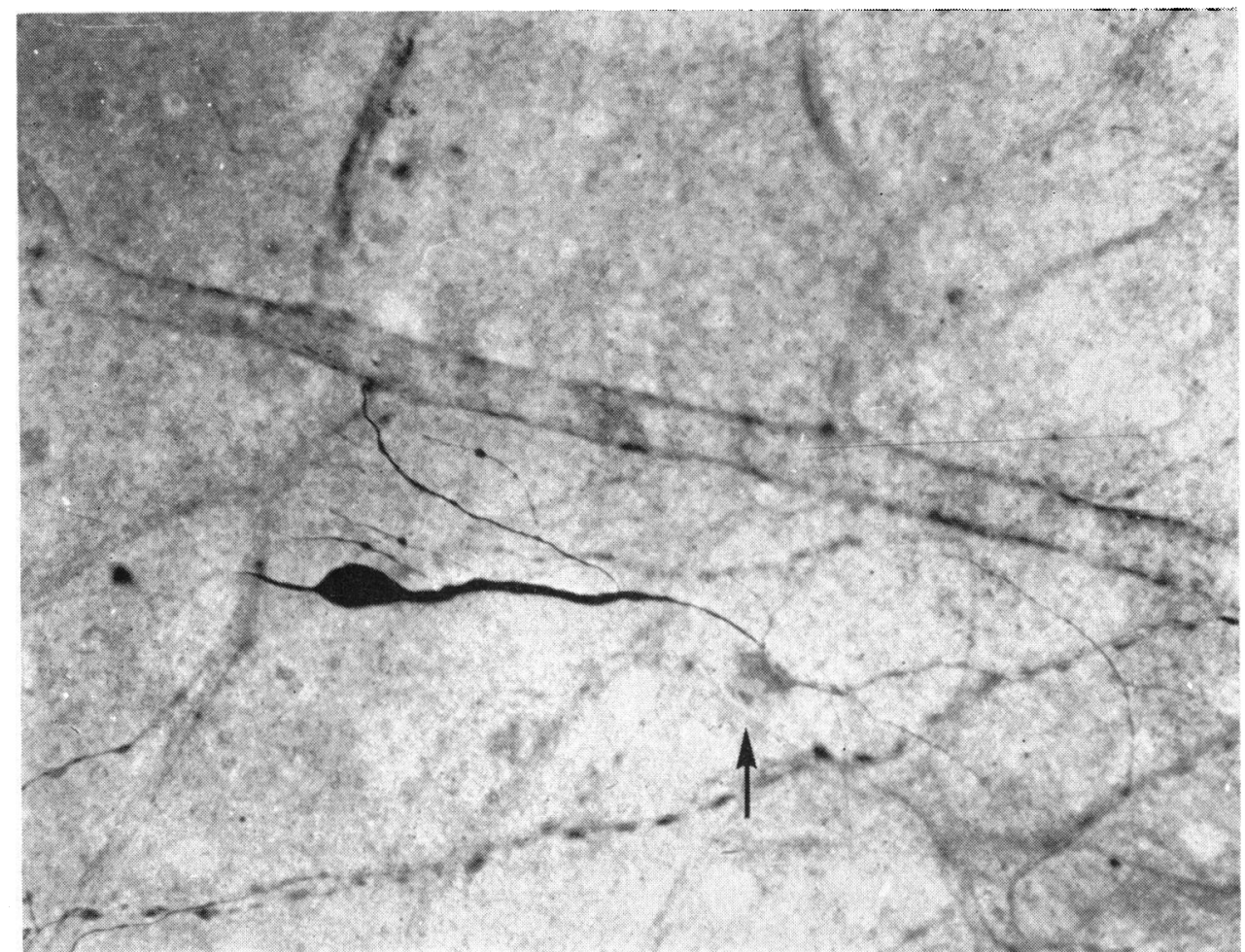

FIG. 4.-Human ganglion cell. The cell body (slightly out of focus) is only slightly impregnated (arrow). Only one of numerous dendrites is thickened and heavily impregnated and bears a growth cone with fine sprouts. $\times 80$

Axons.- Regenerating axons with growth cones, as shown by Wolter $(1956,1961)$ in pathological conditions, were found pursuing a straight path through the retina; they either proceeded normally to the optic nerve head, or described sinuous pathways across the beautifully regular pattern of the normal axons. Their tortuous course and increased argyrophilia enabled them to be identified and followed with ease (Fig. 9).

In the aged retina axons attempting regeneration were more often obstructed, sometimes by a retinal artery and sometimes by some other obstacle not evident in whole mounts. Such arrested axons follow a looped course and end against a new obstacle where they give off collateral shoots (Fig. 10). Tello (1907), in his experimental sectioning of the optic nerves, observed in the retina as well as in the optic nerve similar features of the regenerating axons, i.e. sinuous pathways and grapelike forms with multiple balls, rings, and cones at the growing end of the axon instead of a single growth cone. The behaviour of an axon coming up against the wall of an artery is typical; as there seems to be too little space between the artery and the internal limiting membrane, the axon ends in a large, irregular plate with many marginal sprouts. Before ending in such a plate, the axon gives off collateral branches at right angles; these collateral branches run parallel to the artery and-at 


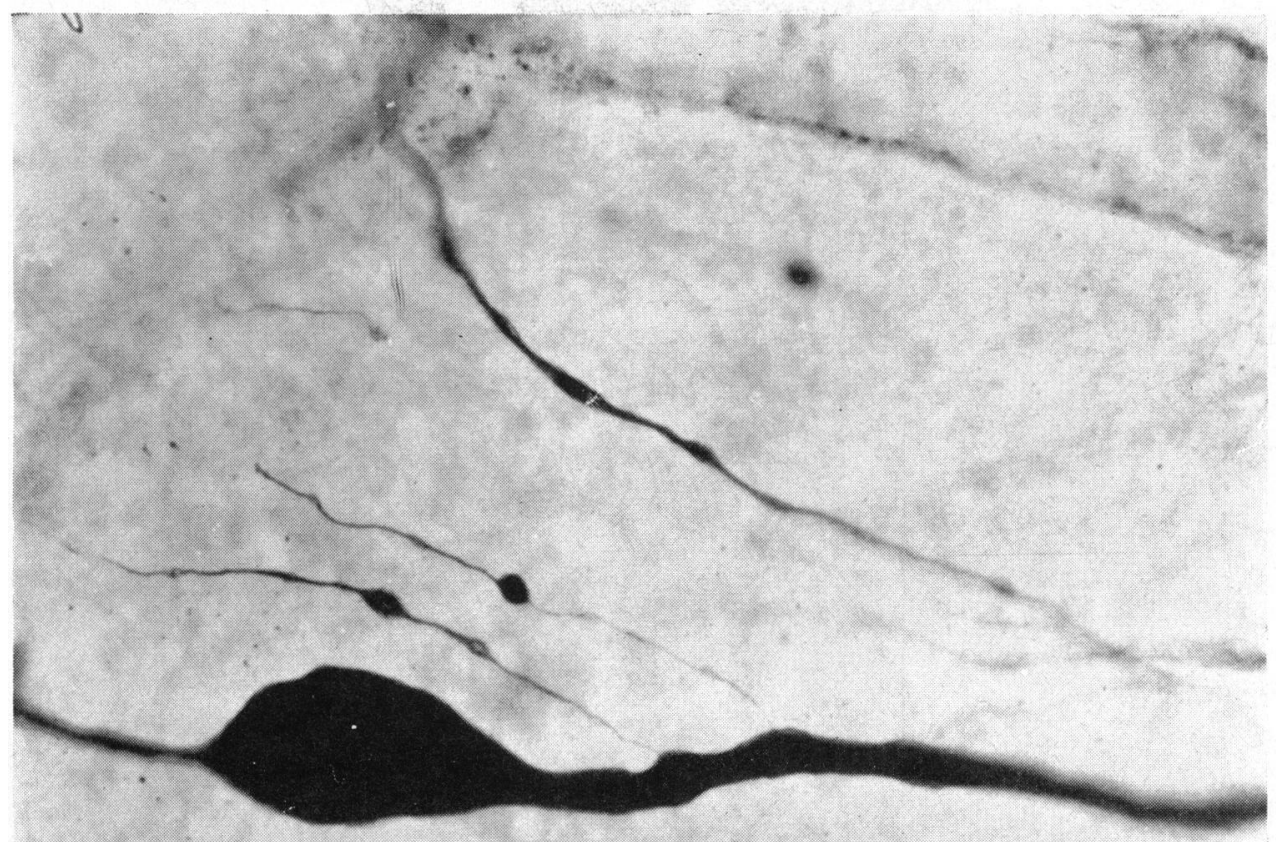

FIG. 5.-Detail of Fig. 4, showing searching twigs sprouting from the growth cone. These are very fine and contain drops of accumulated neuroplasm; otherwise they are smooth and fine. $\times 380$

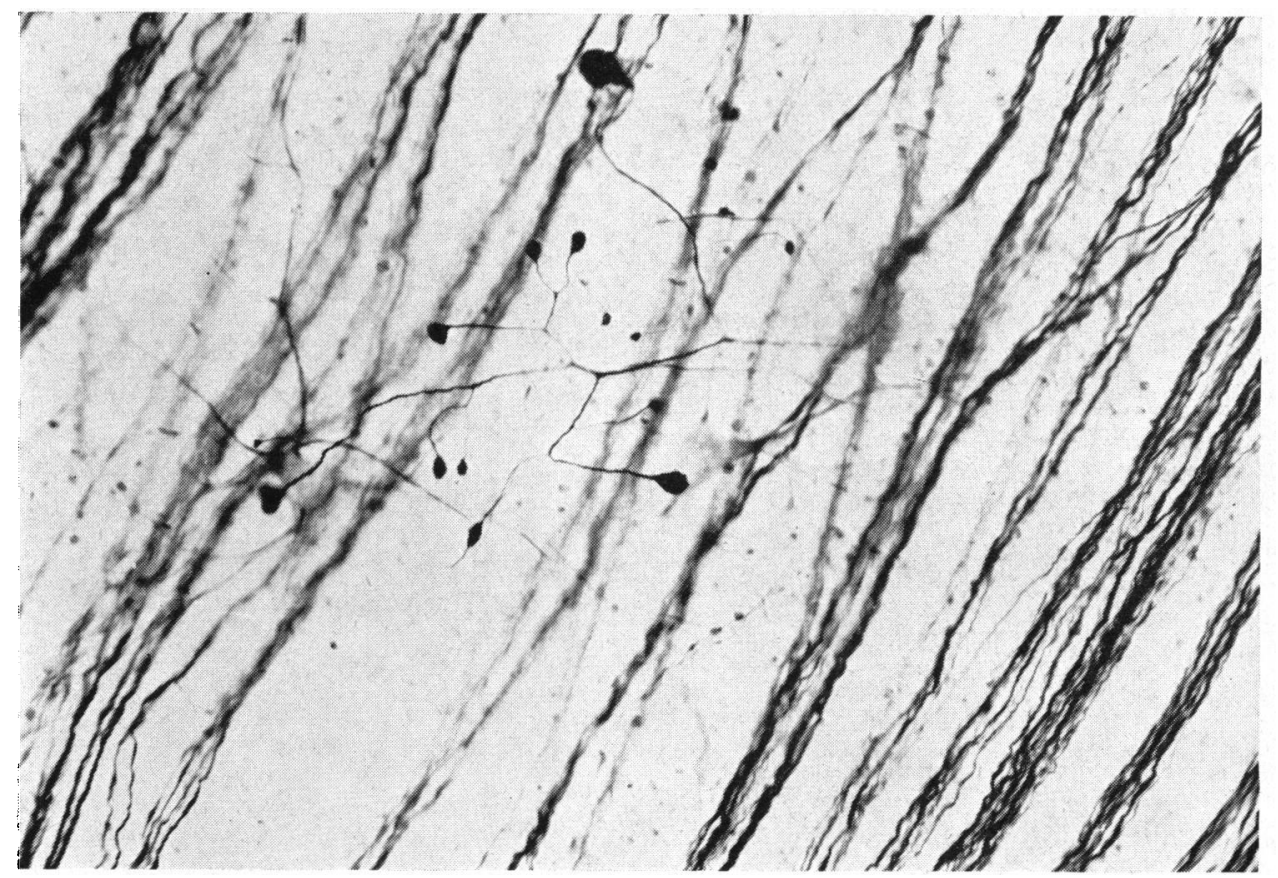

FIG. 6.- Human retinal ganglion cell. Only one dendrite is thickened and bears many retraction balls on the tips of the branches as well as some growth cones with searching fibres. $\times 80$ 


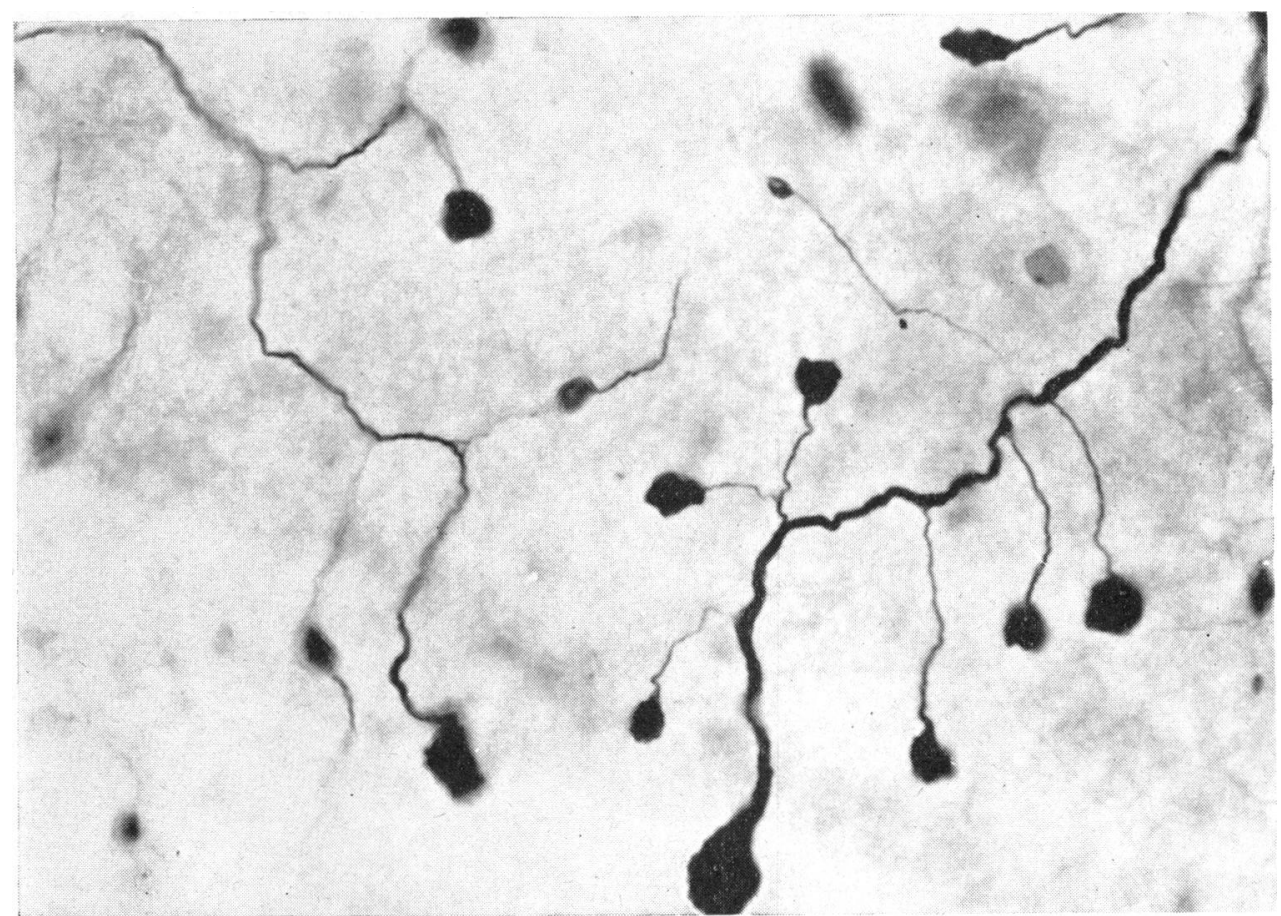

FIG. 7.-Detail of another ganglion cell, showing dendrites with each branch ending in retraction balls. $\times 380$

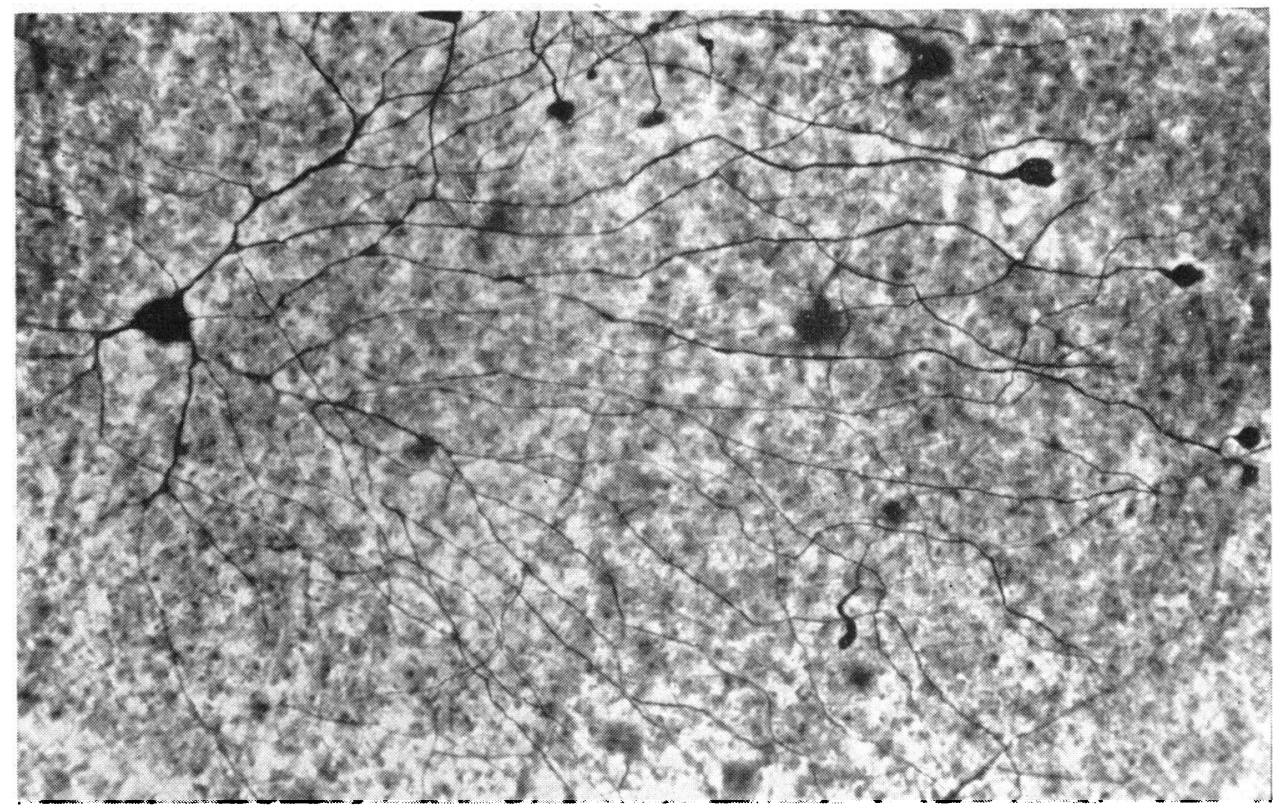

FIG. 8.-Retinal ganglion cell with some dendrites apparently normal and others-also very fine and smooth-ending with retraction balls and growth cones. $\times 80$ 


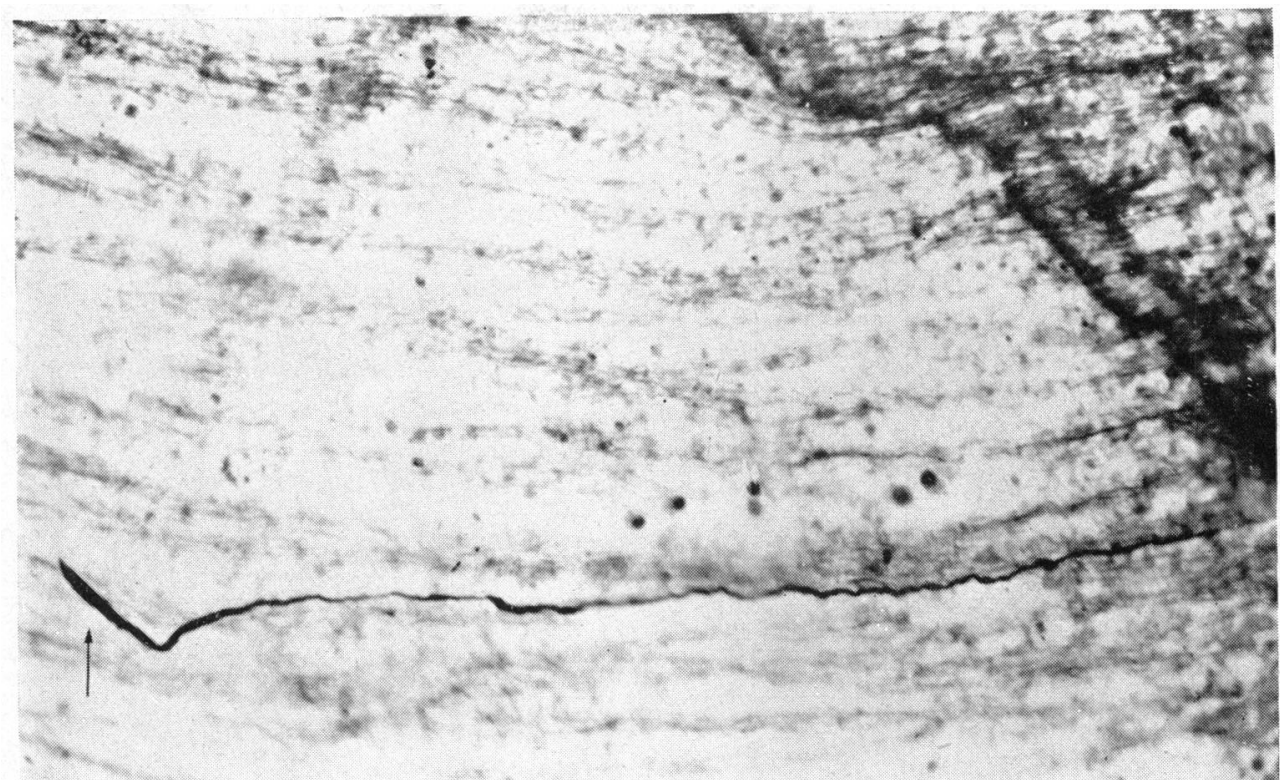

Fig. 9.-Growing axon from a human retina (75 years) ending in a solitary growth cone (arrow). Strong argyrophilia of the whole axon. $\times 80$

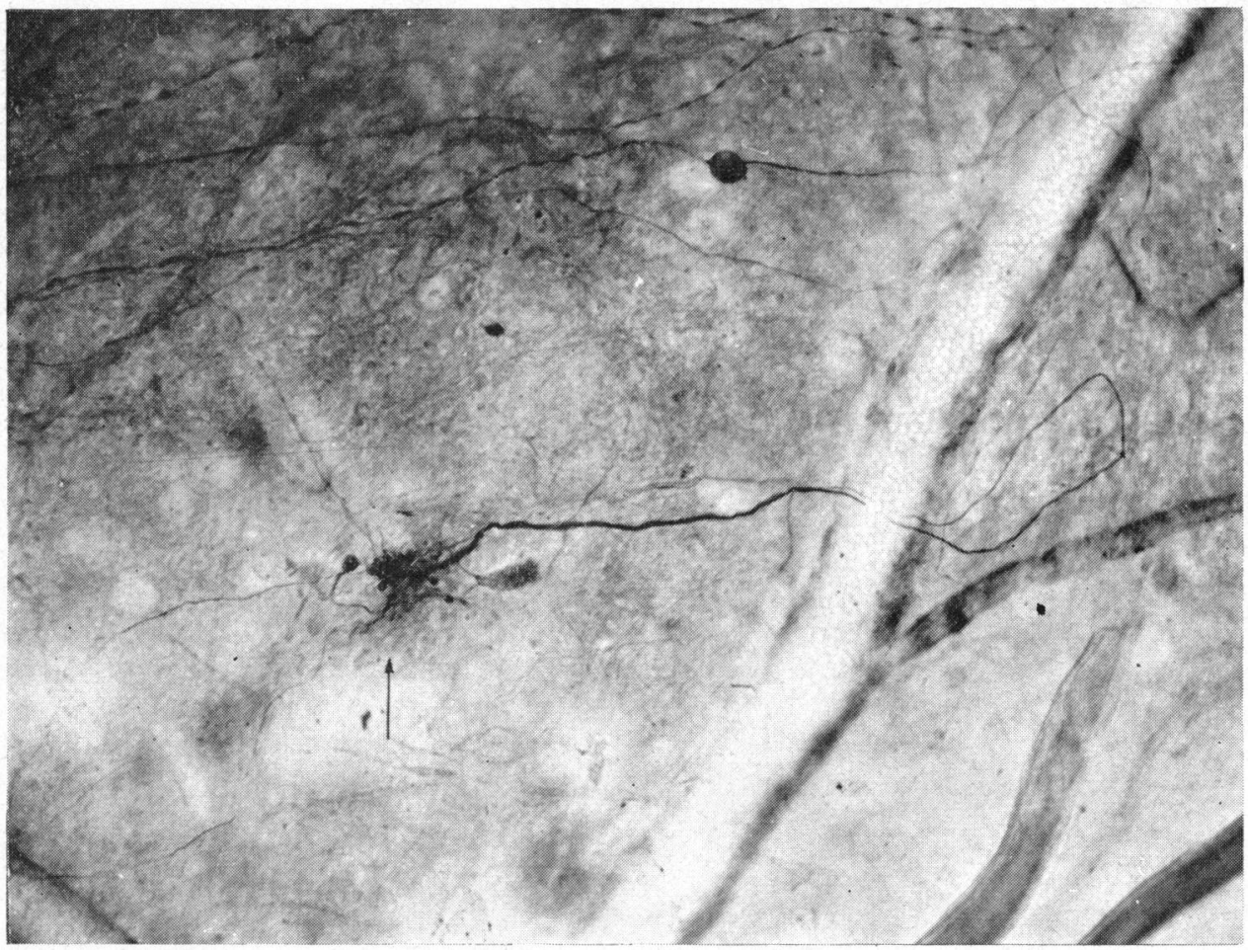

FIG. 10.-Another axon of the human retina growing in a loop across an artery and turning back to its place of origin (arrow). Its growth being stopped, the axon tip sends out several enlargements and cones or plates of growth. Spherical swelling of another retinal axon is clearly seen above. $\times 80$ 
some distance from the original axon-try again to surmount the obstacle, so giving rise to new enlargements and sprouts (Figs 11 and 12).

In the trabecular meshwork of the eyes examined, similar but more numerous changes were seen at an earlier stage than in the retina. Their detailed form will be described elsewhere.

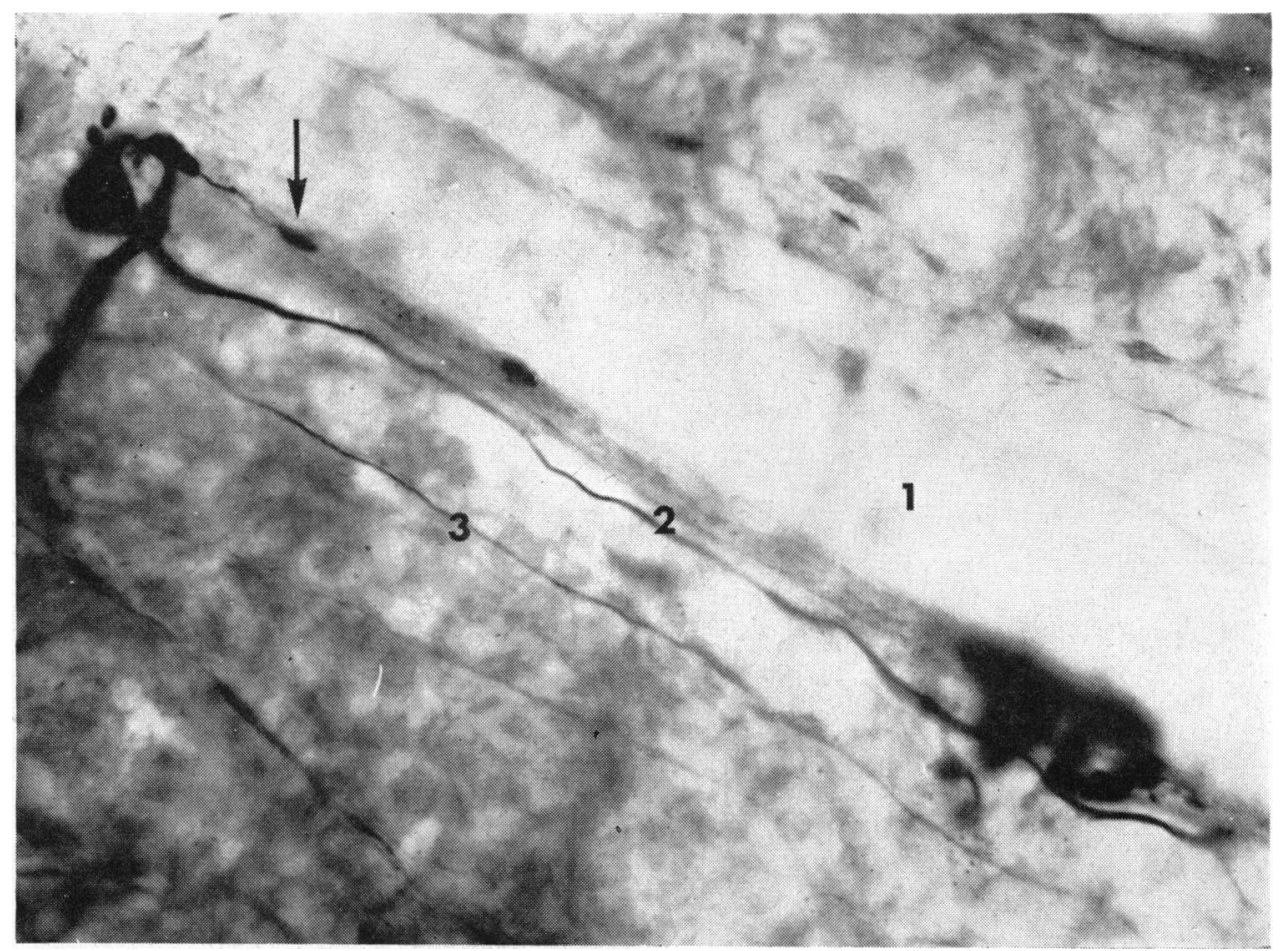

FIG. 11.-Human retina. A growing axon (extreme left) has been stopped in its progress by an artery (1). The blocked end is enlarged and sends out some very short growth cones and a thin, short collateral twig ending in a growth cone (arrow). Two longer collateral branches $(2,3)$ extend along the artery, perpendicular to the original axon. One (3) is long, the other (2) ends in several growth plates, cones, and rings. $\times 800$

\section{Comment}

The method used for this study proved to be useful in that artefacts were eliminated. Whole mounts of the retina preserve the normal connexions of tissue elements as well as intact cells and their processes. The only possibility of damaging the tissues arises while the retina is passed through the different steps of the method, the whole procedure being carried out on the slide. The most difficult process is the removal of the vitreous before impregnation; every remnant of vitreous impairs impregnation and, as it takes up silver, prevents the study of the impregnated elements obscured behind it. Fortunately, the vitreous of senile eyes is mostly liquid and can be more easily removed. Gros-Schultze's method gives an excellent picture of the whole nerve fibre layer of the retina and of the very varied types of ganglion cells. In some animals, such as the cat and rabbit, even the horizontal 


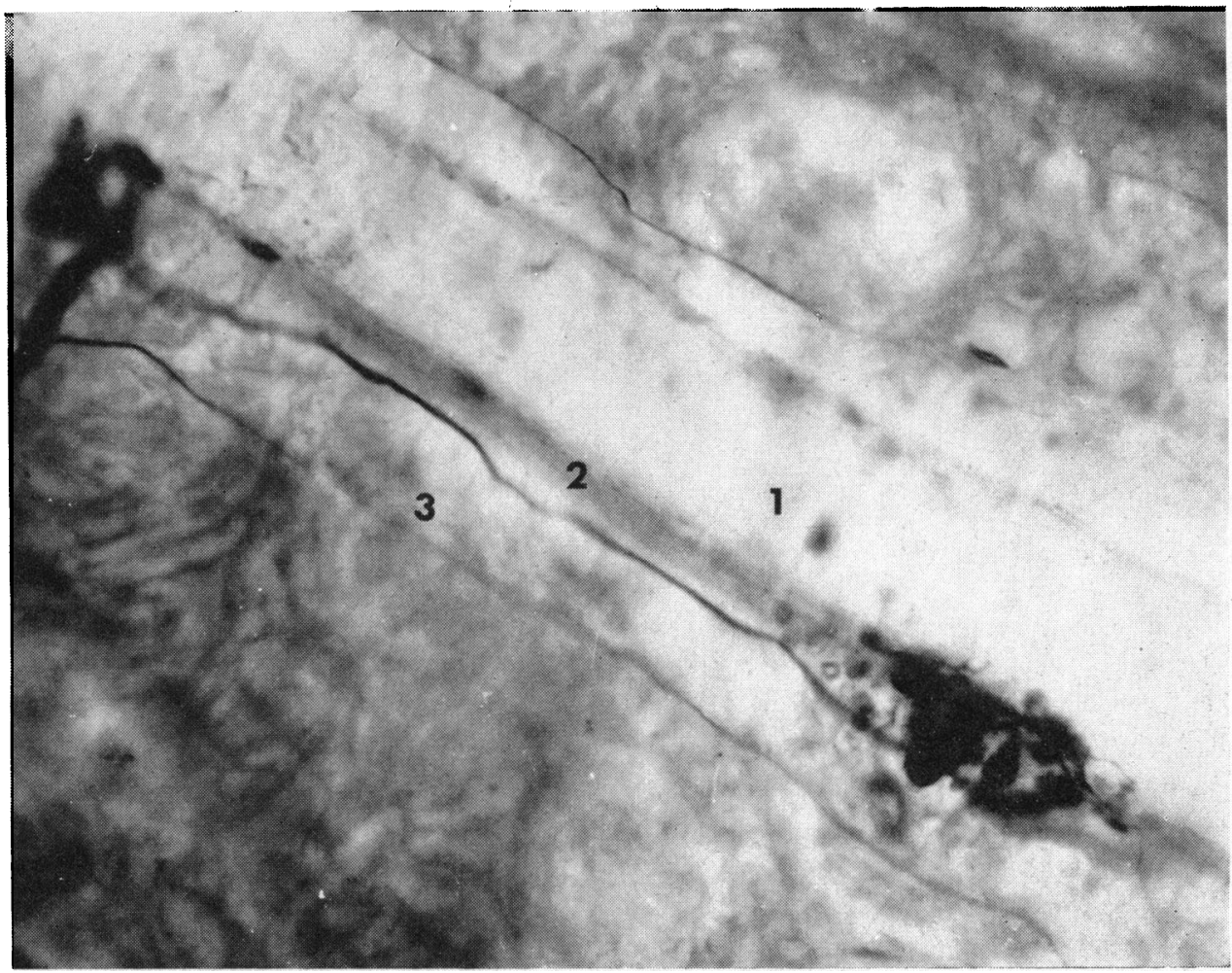

Fig. 12.-A more superficial plane from the same area. Numerous sprouts of the axon collateral (2) are in focus, some ending in rings, some in enlarged plates, and others in fine fibres. $\times 800$

cells are impregnated and can be studied by focusing at another level. It is, of course, not possible to follow vertical connexions with the other neurons of the retina. However, indications of similar changes have been seen in many Rhesus monkey retinae studied by the Golgi method (Figs 13 and 14) but it is not possible as yet to be sure of their importance.

Retinal tissue has many advantages for the study of changes in the dendrites. The dendrites in the central nervous system have been studied by Ramon y Cajal (1928) and by Lafora (1914, quoted by Cajal), but as only thin sections can be used, only fractions of such dendrites are available for investigation. In the retina, ample dendritic trees can easily be studied in their finest details.

From the present study the following points emerge.

There is a large degree of plasticity in the peripheral as well as in the central nervous system. In the periphery-especially in the constantly renewed epitheliawe must presume continuous regeneration of the nerve-endings (Eiisager and Weddell, 1962; Fitzgerald, 1959, 1961, 1962). In Pacinian corpuscles this growth of the nerve fibres was demonstrated by Cauna (1958) and Cauna and Mannan (1958), who considered the replacement of the nerve-endings to be a physiological process of adaptation to changing functional conditions. This plasticity seems to be present even in the central nervous system as dendrocytogenesis is known to remain 


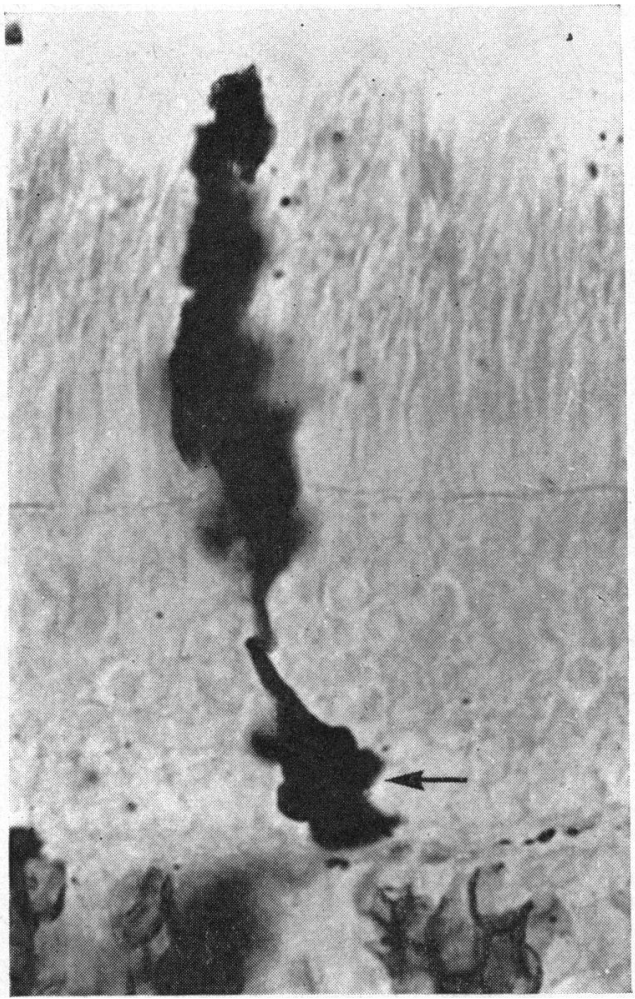

FIG. 13.--Retina of Macaca mulatta impregnated by the Golgi-Cajal method. A cone with grossly enlarged cone pedicle (arrow) is seen ending sharply against the border of the outer plexiform layer. A horizontal fibre of a horizontal cell is seen passing through the outer plexiform layer to the cone pedicle. $\times 800$

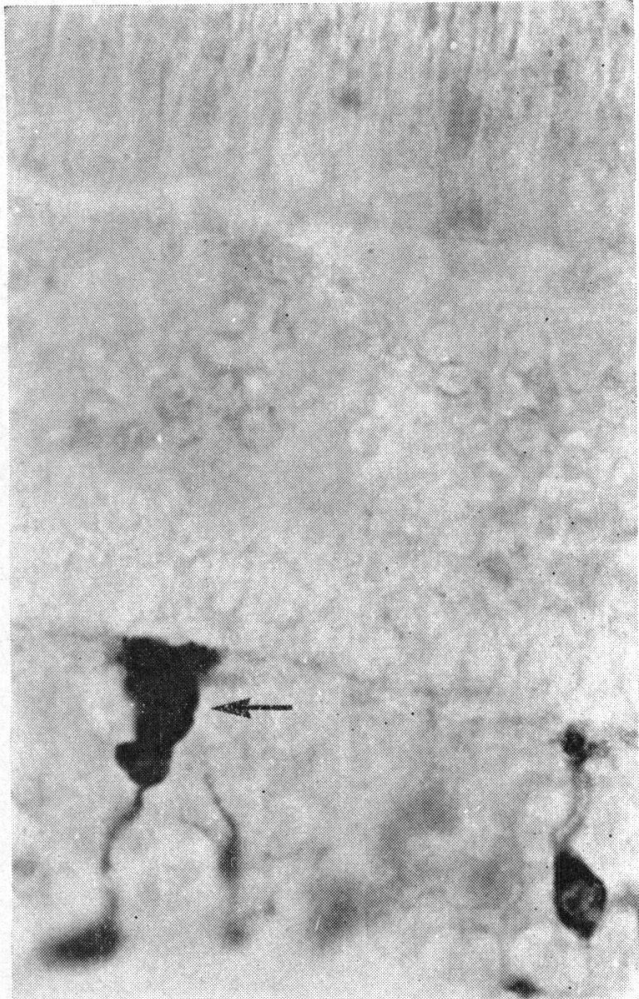

FIG. 14.-Same retina as Fig. 13, showing a bipolar cell with enlarged upper protoplasmic process (arrow) ending against the outer plexiform layer. On the right is a normal upper dendritic stem of a bipolar cell for comparison (slightly out of focus). $\quad \times 800$

active throughout life. It would seem likely that in the retina such changes entail a reparative process, as the receptive pattern of the retina should be-at least in the adult-kept more constant than the pattern in some associative areas of the cerebral cortex. Regenerative possibilities have been described in the central nervous system by many authors (summarized by Cajal, 1928). The existence of reparative changes in an isolated branch or dendrite seems important; one would expect to find some metabolic or pathological condition of the whole neuron, but the frequent occurrence of isolated changes leads us to consider other probable causes, such as localized changes - degenerative or metabolic - in the vicinity of the growing dendrite or a loss of the functional connexions of the dendritic tree. Of these the latter seems the most probable.

Degenerative changes in the vicinity of a neuron would also affect dendrites of other cells as their territories often overlap. In the more widespread dendritic changes, however, we can accept the existence of some degenerative changes in the neighbourhood, leading to the collateral sprouting of new fibres as seen in the re-innervation of muscles by Wohlfart (1957). Fine terminal twigs sprouting from 
the cones of growth are similar to those demonstrated by Urra (1921) in the ganglion cell layer of the developing retina; Urra suggested that they represented searching fibres trying to establish the correct course for deviated axons. If such deviated axons can still reach their destination-the optic nerve head-they can survive, otherwise, having no functional connexions, they remain sterile and soon disappear.

These changes in the retinal axons may be explained by the theory of a constant flow of the axoplasm from the cell body to the periphery; this flow is supposed to take place in the embryonal growth of axons (the vis a tergo of His and Held quoted by Cajal, 1952) as well as in adult life by the "damming" of axoplasm (Weiss and Hiscoe, 1948). We must, of course, recognize the existence of a constant flow of substances along the living axon: only its direction is in question. His, Held, Cajal, Weiss, and others accept a centrifugal flow, but the excellent work of Hughes (1953) on tissue cultures of the nervous tissue has shown that it is possible to register a constant movement of pinocytic vesicles or vacuoles from the periphery to the cell body. It would seem probable, therefore, that movement occurs in both directions, proteins - as Weiss suggested - being supplied by the cell body, especially the nucleus, and water and perhaps some other substances being accepted by the axon from the neighbouring cells. As described by Vrabec (1955b) in regenerating fibres of the human cornea, pseudopodiae of the enlarged growing fibres can reach the keratocytes; a more regular phenomenon is the drop-like enlargement of sprouting fibres in the vicinity of every keratocyte nucleus situated along their path. Such smooth fibres show many vacuoles. A metabolic interaction between them and the keratocytes is probable as they are mostly, in the first period of their growth at least, naked and deprived even of the sheath of Schwann (Rexed and Rexed, 1951). This regular enlargement of fibres in the vicinity of all the nuclei which they pass supports the hypothesis of Weiss of the renewal of their proteins through nuclear activity. In the fast-growing regenerated fibres in the corneal stroma, Schwann cells grow along the naked fibres only at a later stage. It seems possible that the proteins of naked fibres could be partly supplied from neighbouring cells. The damming of the neuroplasm is more evident in the trabecular meshwork, where spatial restrictions can arise precociously owing to the sclerosing of the thick connective trabeculae. As previously shown (Vrabec, 1954a, b; 1955a, etc.), many unsuspected conditions may shape the innervation pattern of clinically "normal" eye tissues. Some such modifications were described by Dogiel (1890), Attias (1912), and Lauber (1936) as a part of the normal innervation of ocular tissue, but are, in fact, early pathological changes in the innervation pattern.

Referring again to the question of senile changes in the innervation pattern of the eyeball, it should be remembered that the constant growth after birth of axons in the cells of the sensory ganglia, as well as the frequent appearance of outgrowth of the cells and axons in senility and in pathological conditions, has been known for a long time (Cajal, 1928; de Castro, 1922). It seems more probable-in our opinion-that they are often merely the expression of changes in the functional or metabolic state of the elements, and that they are sometimes reactive or reparative in character.

In contrast to the ageing of mesodermal tissue, it seems that the continuation of active function may retard the senile decline of neuro-ectodermal components. 


\section{Summary}

Sixteen human adult retinae from different decades, together with the trabecular meshwork of the same eyes and many other mammalian retinae, were examined by a modification of Gros-Schultze's method. Changes in the normal pattern of innervation and the possible causes thereof are discussed with reference to other work on the subject.

With the exception of Figs 13 and 14, all other illustrations are whole mounts of the retina impregnated by the method of Gros-Schultze.

\section{REFERENCES}

Attias, G. (1912). Albrecht v. Graefes Arch. Ophthal., 83, 207.

CASTRO, F. DE (1922). Trab. Lab. Invest. biol. Univ. Madr., 19, 241.

Cauna, N. (1958). J. Anat. (Lond.), 92, 640. and Mannan, G. (1958). Ibid., 92, 1.

CoËrs, C., and Woolf, A. L. (1959). "The Innervation of Muscle". Blackwell, Oxford.

Dogiel, A. S. (1890). Anat. Anz., 5, 483.

EIISAGER, M., and WeDdell, G. (1962). J. Anat. (Lond.), 93, 584.

FitzGerald, M. J. T. (1959). J. Anat. (Lond.), 93, 584.

(1961). Ibid., 95, 495.

(1962). Ibid., 96, 189.

Hughes, A. (1953). Ibid., 87, 150.

LAFORA, G. R. (1914). Trab. Lab. Invest. biol. Univ. Madr., 12, 1. Quoted by Ramon y Cajal (1928).

LAUBer, H. (1936). In "Handbuch der mikroskopischen Anatomie des Menschen", ed. W. von Möllendorff, vol. 3, pt 2, pp. 9-616.

Ramon y Cajal, S. (1928). "Degeneration and Regeneration of the Nervous System", trans. and ed. R. M. May. Oxford University Press, London. (1952). " "Histologie du système nerveux de l'homme et des vertébrés". Centenary edition, Madrid. [Orig. 1909-1911, trans. L. Azoulay. Maloine, Paris.]

ReXed, B., and ReXeD, U. (1951). Brit. J. Ophthal., 35, 38.

Tello, F. (1907). Trav. Lab. Rech. biol. Univ. Madr., 5, 237.

UrRa, M. (1921). Ann. Oculist. (Paris), 158, 43.

VRABEC, F. (1954a). Wiss. Z.Ernst Moritz Arndt-Univ. Greifswald., Math.-nat. Reihe, 4, 99. (1954b). Ophthalmologica (Basel), 130, 24. (1955a). Acta anat. (Basel), 25, 273.

(1955b). Ophthalmologica (Basel), 130, 24.

(1956). Ibid., 131, 73.

(1965). Brit. J. Ophthal., 49, 113.

Weiss, P., and Hiscoe, H. B. (1948). J. exp. Zool., 107, 315.

Wohlfart, G. (1957). Neurology (Kbh.), 7, 124.

Wolter, J. R. (1956). Albrecht v. Graefes Arch. Ophthal., 158, 235.

- (1957). Amer. J. Ophthal., 44, no. 5, pt 2, p. 48.

- (1961). Klin. Mbl. Augenheilk., 138, 83.

(1963). Acta ophthal. (Kbh.), 41, 343. 